Biografistyka Pedagogiczna

Rok 6 (2021) $\mathrm{nr} 1$

ISSN 2543-6112; e-ISSN 2543-7399

DOI: $10.36578 /$ BP.2021.06.15

\title{
Barbara Toroń-Fórmanek*
}

\section{Przestępczy styl życia w perspektywie biograficznej skazanych kobiet i mężczyzn \\ Criminal Lifestyle from the Biographical Perspective of Convicted Men and Women}

\begin{abstract}
The concept of 'lifestyle' has become popular in recent years. It is used in the language of marketing and advertisements, colourful magazines and on social networking sites. Lifestyle theories were developed in social sciences between the late nineteenth and early twentieth centuries. Even Max Weber was among the many theorists. The concept of 'criminal lifestyle' to some extent refers to these earlier concepts. Distinguishing it from the general concept of 'lifestyle' allows the reasons that motivate people to commit crimes to be better understood. The use of quantitative methods to examine the criminal lifestyle theory has not led to an accurate understanding of the genesis of these phenomena and behaviours and their practical use. This was because the results largely did not reflect the socio-psychological determinants of criminal lifestyle. Therefore, qualitative methods, including the biographical method, should be considered the best to use. The biographical method consists of getting to know the entire biographies of convicts from the earliest years of their childhood to the present days. The tools and techniques used include interviews with convicted persons and the analysis of various written sources, including documents created by respondents and prison files. The research method that involves getting to know the biographies of men and women serving prison sentences shows that the criminal lifestyle theory has practical application in the classification of criminal behaviour. The process of social rehabilitation using the biographical method and the analysis of the research

* Barbara Toroń-Fórmanek (ORCID: 00oo-0oo3-1699-3679) - dr hab. prof. Uniwersytetu Zielonogórskiego, kierownik Pracowni Resocjalizacji i Pedagogiki Penitencjarnej na Wydziale Pedagogiki, Psychologii i Socjologii uz, kontakt: btoron@wp.pl.
\end{abstract}


material obtained based on the criminal lifestyle theory seems to be so effective that it can be used in practice with great success. There is only one condition: those who use it must have appropriate practical skills.

Keywords: lifestyle, criminal lifestyle, biography, curriculum vitae, prison, rehabilitation, imprisonment, men, women, recidivists, prison, prison, crime.

$\mathrm{P}$ ojęcie „styl życia” jest jednym z terminów socjologicznych pojawiających się często w języku potocznym, mediach i publikacjach. Bywa ono używane $\mathrm{w}$ rozmaitych sytuacja i kontekstach: np. dietetycy, lekarze oraz specjaliści od zdrowia zwracają uwagę na „zdrowy styl życia”, twórcy reklam przekonują, że produkt X lub Y jest objawem określonego stylu życia, a znawcy mody uważają, że jakiś sposób ubierania jest przejawem określonego stylu życia ${ }^{1}$. Uzus językowy tego pojęcia jest dosyć różnorodny i w zasadzie obejmuje różne, niejednokrotnie wzajemnie wykluczające się sytuacje². To obliguje do zadania pytania: czym właściwie jest „styl życia”?

Należy zacząć od tego, że omawiany termin jest używany na gruncie socjologii oraz ekonomii. Za jego „ojca” uchodzi Thorstein Veblen, który prowadził badania nad przedstawicielami klas próżniaczych. W dużej mierze zagadnienie stylu życia zostało dopracowane przez niemieckiego socjologia i politologa Maxa Webera. Oprócz niego badania nad stylem życia prowadzili Albert Thomas oraz François Simiand. Pierwszy z nich był amerykańskim socjologiem, który starał się porównać sposób życia amerykańskich i europejskich pracowników fabryk Forda. Badania wykazały, że Amerykanom zależy na wyższym

1 I. Sowa, Wykorzystanie koncepcji stylu życia $w$ typologii młodych konsumentów, „Studia Ekonomiczne. Zeszyty Naukowe Uniwersytetu Ekonomicznego w Katowicach", 303 (2016) nr 7 s. 135-149.

2 W. Gruszczyński, Jeszcze raz o systemie, normie i uzusie, w: Polszczyzna moja... Księga jubileuszowa $z$ okazji 40-lecia pracy naukowej i dydaktycznej profesora Jerzego Bralczyka (109-119), red. G. Dąbkowski, D. Lewandowska-Jaros, Warszawa 2009, s. 109-119. 
standardzie życia, lepszym mieszkaniu, zarobkach i wyżywieniu ${ }^{3}$, natomiast Europejczykom na większej liczbie czasu wolnego. W ten sposób wykazał on, że pracownicy tej samej firmy w dwóch różnych miejscach na świecie różnią się między sobą stylem życia. Natomiast zdaniem Françios Simianda owe różnice mają związek z kreacją stylu życia przez pojawiające się wówczas reklamy ${ }^{4}$.

W klasycznym ujęciu „styl życia” jest definiowany m.in. jako formy codziennych zachowań każdego człowieka z osobna powodujące, że dana jednostka odróżnia się od innych ${ }^{5}$. Ewentualnie można go rozumieć jako zespół cech przypisany konkretnej zbiorowości, postrzeganych jako specyficzne dla członków tych zbiorowości codzienne czynności lub zachowania. Dodatkowo na omawiane zjawisko wpływają czynniki obiektywne: uwarunkowania ekologiczne, ekonomiczne, wykształcenie oraz społeczne i perspektywa czasowa ${ }^{6}$. Uznaje się także, że może on różnicować się w zależności od narodowości, akceptowanego systemu aksjologicznego oraz odczuwanej hierarchii potrzeb oraz wyznawanych koncepcji ideologicznych ${ }^{7}$.

Jednocześnie należy podkreślić, że pojęcia „styl życia” nie można mylić z takimi terminami jak: „tryb życia”, „sposób życia” lub „poziom życia”. Styl życia to, najprościej ujmując, sposób zaspokajania ludzkich potrzeb przy istniejących zasobach materialnych, otoczeniu człowieka, przynależności grupowej itp. ${ }^{8}$.

W 1997 r. Glenn D. Walters, badacz zajmujący się zagadnieniami pozostającymi na pograniczu kryminologii i socjologii, opracował koncepcję przestęp-

3 J. Kłos, Zjawisko zdrowego stylu życia we współczesnym społeczeństwie polskim, Poznań 2014, s. 22-24.

4 J. Zalewska, Kategorie stylów życia w twórczości naukowej Elżbiety Tarkowskiej, w: Socjologia czasu, kultury i ubóstwa. Księga jubileuszowa dla profesor Elżbiety Tarkowskiej, red. K. Górniak, T. Kanasz, B. Pasarnonik, J.Zalewska, Warszawa 2015, s. 157-166.

5 A. Sciński, Styl życia - problemy pojęciowe i teoretyczne, w: Styl życia. Koncepcje i propozycje, red. tegoż, Warszawa 1976, s. 15-16.

6 M. Halamska, Żyć na wsi. Elementy stylu życia, „Wieś i Rolnictwo”, 1 (2021) s. 25-27.

7 M. Wszołek, Styl życia w komunikacji społeczeństwa, „Studia Ekonomiczne. Zeszyty Naukowe Uniwersytetu Ekonomicznego w Katowicach", 313 (2017) s. 187-189.

8 D. Piotrowska, Styl życia. Uwagi ogólne, „Zeszyty Naukowe Wyższej Szkoły Pedagogicznej w Bydgoszczy. Studia z nauk społecznych", 2 (1998) s. 62. 
czości jako stylu życia ${ }^{9}$. Przedstawił ją w postaci kilku założeń, przy pomocy których wskazywał, z jakiego powodu przestępczość należy uznać za jeden z modeli stylów życia. Warto w skrócie przybliżyć owe założenia. Po pierwsze, zauważył on, że przestępczość przejawia się w stylu życia charakteryzującym się brakiem odpowiedzialności, która wynika z pobłażliwości w traktowaniu przestępców. Po drugie, rozwój przestępczości wynika z pewnych czynników biologicznych, społecznych oraz psychologicznych. Po trzecie, uwarunkowania ekonomiczne i społeczne mogą w jakimś stopniu determinować wstąpienie na drogę przestępczości, ale nie jest to obligatoryjne. Po czwarte, przestępczość ma związek z postawą życiową ludzi. Zazwyczaj dotyczy to osób, które czują się przegrane w życiu, które dodatkowo za swoje porażki usprawiedliwia jedynie czynnikami zewnętrznymi. Tym samym chętnie zaczyna ona przebywać wśród osób cechujących się skłonnościami do dewiacji społecznych. Walters podaje, po piąte, że osoba zmierzająca ku przestępczemu stylowi życia posiada charakterystyczny sposób myślenia, dostrzegany na kilku płaszczyznach, np. społecznej czy ekonomicznej ${ }^{10}$. Ten sposób myślenia ma za zadanie usprawiedliwić działania polegające na złamaniu prawa oraz wytłumaczyć się przed samym sobą z pobłażania sobie. Kolejne założenie jest rozwinięciem poprzedniego i odnosi się do wzorców poznawczych ${ }^{11}$. Natomiast w szóstym punkcie Walters wskazuje, że osoba akceptująca dewiacyjny sposób postępowania posiada szczególne wyostrzone zmysły na obserwowanie pojawiających się okazji do popełnienia przestępstwa. Konsekwencją wszystkich punktów jest ostatnie twierdzenie, które to odnosi się do tego, że nie ma możliwości zmiany przyjętego sposobu zachowania, chyba że dokona się wymiana wszystkich wcześniejszych założeń, czyli części składowych ${ }^{12}$. Zdaniem Marii Ciosek,

9 G. D. Walters, Modeling the Criminal Lifestyle. Theorizing at the Edge of Chaos, Kutztown 2017, passim.

10 M. Czyżewski, Socjologia interpretatywna i metoda biograficzna. Przemiana funkcji, antyesencjalistyczne wątpliwości oraz sprawa krytyki, „Przegląd Socjologii Jakościowej", 9 (2013) nr 4, s. 16.

11 A. Szymański, Przestępcze style myślenia osadzonych w zakładzie karnym a działania penitencjarne, w: Praworządność w dobie XXI wieku red. J. Zimny, Stalowa Wola 2016, s. 423-425.

12 J. M. Stanik, Psychologia sądowa: podstawy, badania, aplikacje, Warszawa 2013, s. 345. 
koncepcja Waltersa za punkt wyjścia przyjmuje, że człowiek nie jest ani dobry, ani zły ${ }^{13}$. Zachowanie uznawane za złe lub dobre jest efektem socjalizacji. Rozwój człowieka związany jest z trzema filarami ludzkiego postępowania:

- ukształtowania więzi społecznych z bliskimi;

- ustalenie swojego poziomu stymulacji;

- uformowanie obrazu samego siebie ${ }^{14}$.

Oznacza to, że osoba żyjąca jako przestępca musi przejść przez cały życiowy proces, aby został ukształtowany jej przestępczy styl życia. W nawiązaniu do koncepcji i modeli stylu życia można stwierdzić, że w jego przestępczym wariancie chodzi również o odpowiednie rozdysponowanie posiadanych środków, umiejętności w celu zarówno indywidualnego, jak i grupowego wyróżnienia się na tle innych jednostek lub grup społecznych. Należy zauważyć, iż niejednokrotnie w przestępczym stylu życia następują całkowicie odmienne uwarunkowania niż w przypadku innych stylów życia. Walters przestawił je w postaci dziesięciu założeń, które, jakby nie patrzeć, mieszczą się w ramach definiowanych w literaturze stylów życia.

W niniejszym artykule chciałabym przeanalizować modele przestępczego stylu życia w biografiach osadzonych mężczyzn i kobiet w kontekście teorii Waltersa. Jest to wycinek z badań, jakie zostały przeprowadzone na biografiach skazanych kobiet i mężczyzn.

Techniki służące do poznania życiorysów, jakimi się posłużono, to obserwacja oraz wywiad ${ }^{15}$. Wszystkie one mają na celu poznanie historii życia (life

13 M. Ciosek, Psychologia sq̨dowa i penitencjarna, Warszawa 2003, s. 74.

14 B. Toroń-Fórmanek Proces resocjalizacji osób pozbawionych wolności $w$ aspekcie nieharmonijnego rozwoju tożsamości, „Lubelski Rocznik Pedagogiczny”, 35 (2016) nr 2, s. 89, DOI: 10 17951/lrp $201635285 .$.

15 M. Malewski, Badania jakościowe wobec postulatu teoretyczności wiedzy, w: Krytyka metodologiczna w praktyce tworzenia wiedzy, red. J. Piekarski, D. Urbaniak-Zając, S. Pasikowski, Łódź 2020, s. 92; T. Pieciuch, A. Molter, Metody jakościowe w badaniach przedsiębiorczości, „Problemy Zarządzania”, 12 (2014) nr 3, s. 249; Metody badań jakościowych, red. N. Denzin, Y. Lincon, t. 1-2, Warszawa 2009; S. Cisek, Metodologia jakościowa we współczesnej informatologii. Wybrane aspekty, „Przegląd Biblioteczny", 3 (2013) s. 300-301; I. Pietkiewicz, J. A. Smith, Praktyczny przewodnik interpretacyjnej analizy fenomenologicznej $w$ badaniach jakościowych $w$ psychologii, „Czasopismo Psychologiczne”, 18 (2012) nr 2, s. 361-368. 
history $)^{16}$. Badania odbyły się w latach 2008-2018 w areszcie śledczym w Nowej Soli oraz w Zakładzie Karnym w Krzywańcu. W pierwszym z wymienionych ośrodków badaniu poddano 14 mężczyzn, z czego 8 to recydywiści, zaś pozostałe osoby odbywały karę pozbawienia wolności po raz pierwszy w życiu. Natomiast w Krzywańcu udział w badaniu brało 48 recydywistów oraz 4 osoby odbywające karę pozbawienia wolności po raz pierwszy. Wśród nich było 52 mężczyzn oraz 21 kobiet. 13 kobiet kolejny raz odbywało karę pozbawienia wolność, 8 zaś pierwszy raz znalazło się w więzieniu. Łącznie w badaniu uczestniczyło 87 osób. Przedział wiekowy mężczyzn to 21-57 lat, a pań 24-63 lat. Wśród tych osób aż 79,3\% to recydywiści, ponieważ to właśnie ta grupa może najlepiej wyjaśnić, na czym polega przestępczy styl życia. Wówczas prowadzone badania miały o wiele szerszy aspekt. W niniejszym artykule zostanie zaprezentowany jedynie mały wycinek badań, który dotyczy aspektów związanych z przestępczym stylem życia. W tym miejscu należy powrócić do tez Waltera, które znajdują odzwierciedlenie w faktach biograficznych kobiet i mężczyzn odbywających karę pozbawienia wolności. Tego rodzaju badania mogą wykazać, że u wszystkich osób pojawią się wspólne elementy zachowania. Będą one podyktowane przyjęciem przez te osoby przestępczego stylu życia. Ze względów na ograniczenia artykułu trudno jest przedstawić tutaj wszystkie życiorysy. Z tego też względu zaprezentowane wyniki będą mieć charakter niejako strukturalny.

W pierwszej kolejności należy odnaleźć cztery charakterystyczne cechy dla przestępczego stylu życia. Wybrane wypowiedzi zostały przedstawione w poniższej tabeli.

16 A. Bron, O badaniach biograficznych krytycznie, „Nauki o Wychowaniu. Studia Interdyscyplinarne", 4 (2017) nr 1, s. 17-19, DOI:10.18778/2450-4491.04.02; J. Pękala, Życie jako biografia. Podejście biograficzne w perspektywie pedagogicznej, Danuta Lalak [recenzja], „Forum Pedagogiczne”, 1 (2014) s. 275-278. 


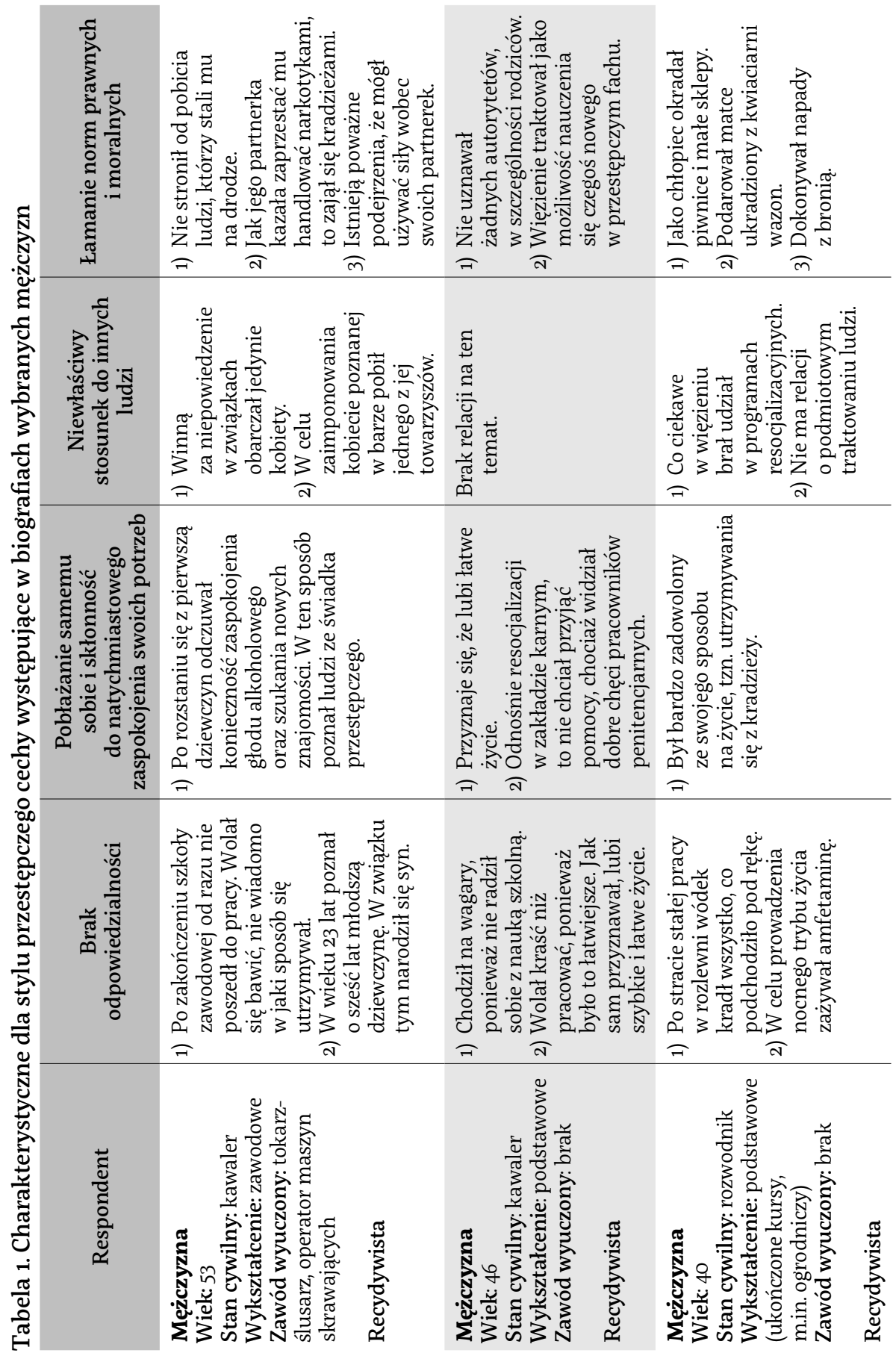




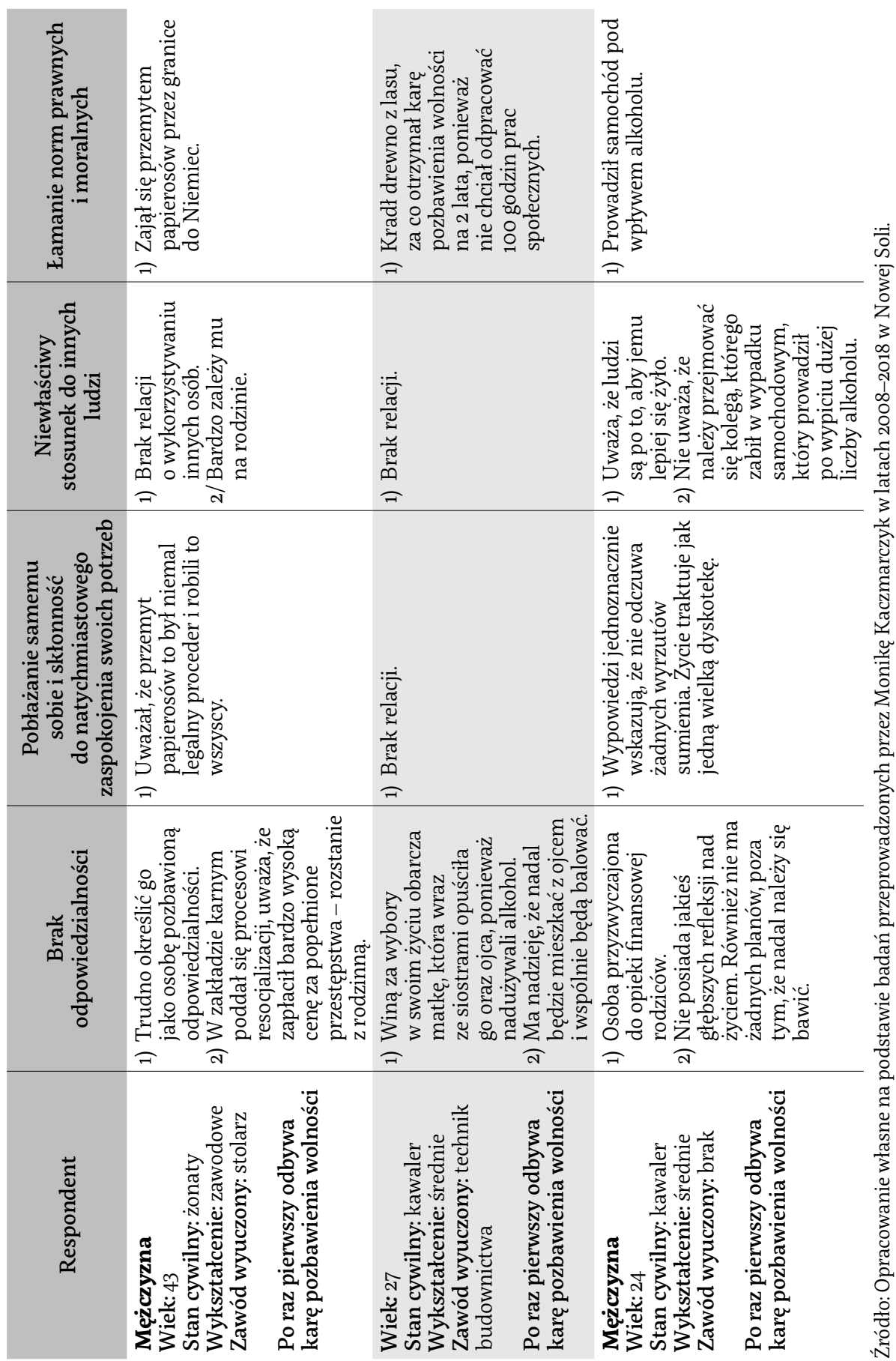




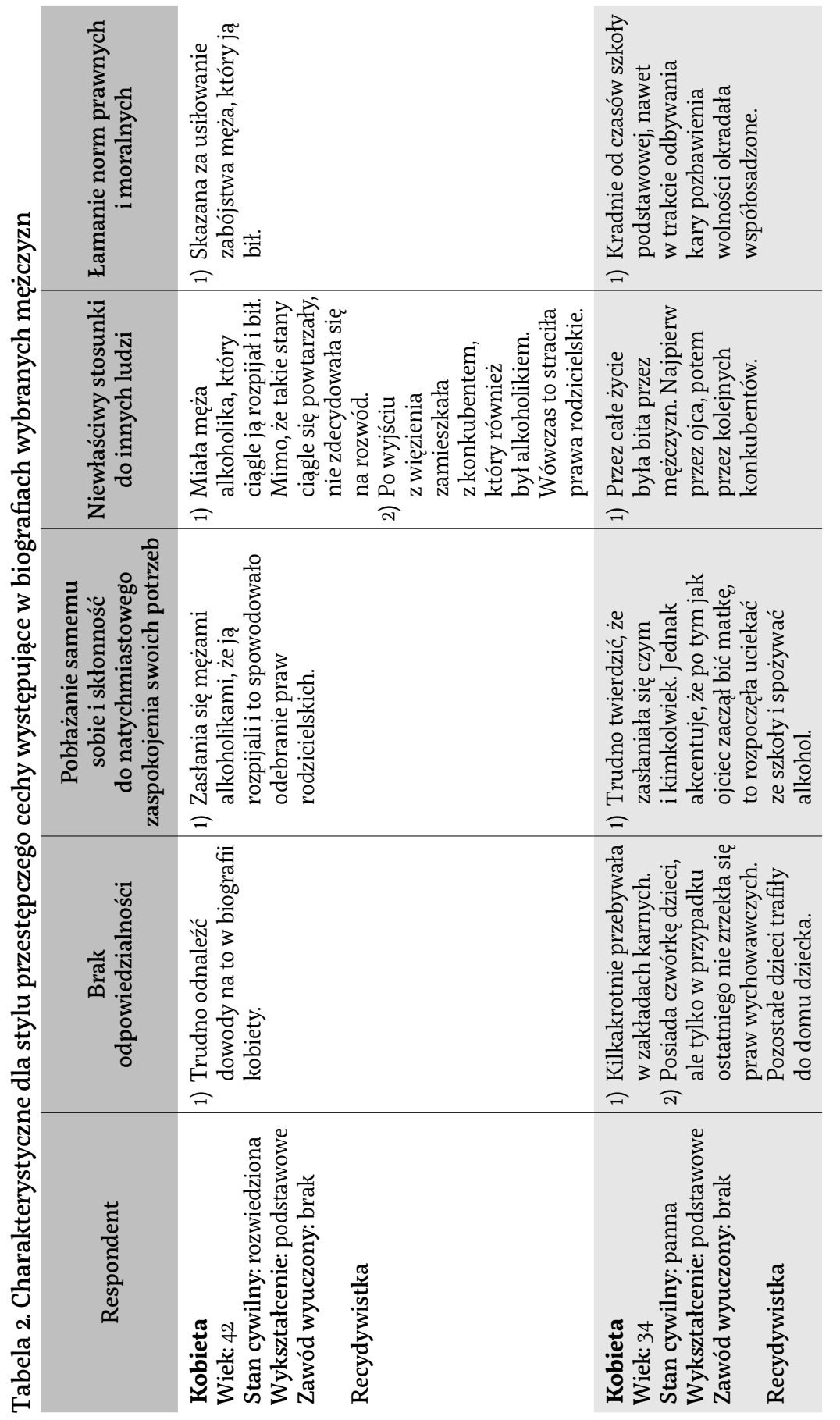




\begin{tabular}{|c|c|c|c|c|}
\hline 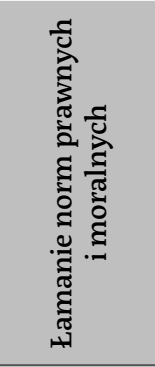 & 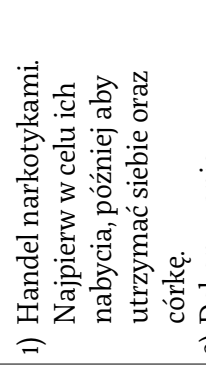 & 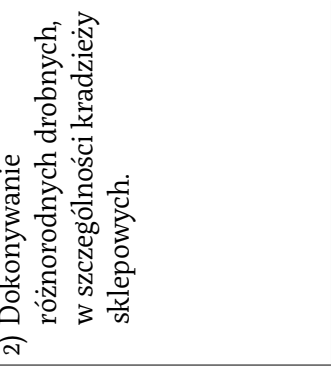 & \multicolumn{2}{|l|}{ 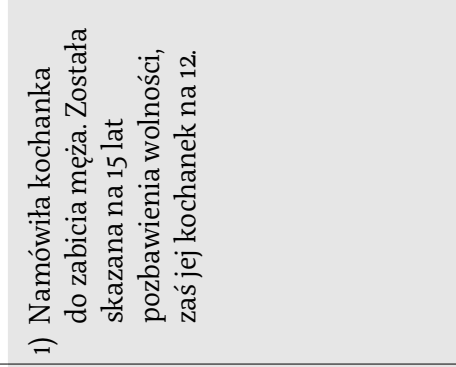 } \\
\hline 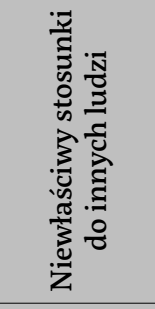 & 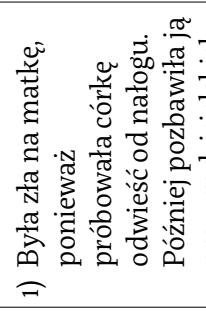 & 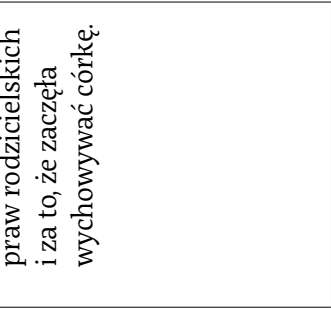 & \multicolumn{2}{|c|}{ 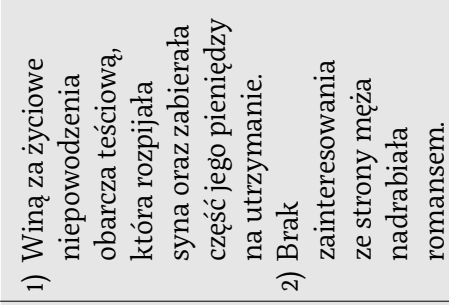 } \\
\hline 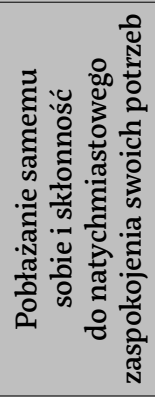 & 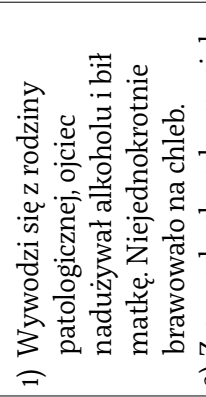 & 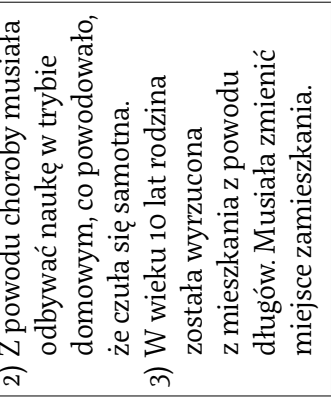 & \multicolumn{2}{|c|}{ 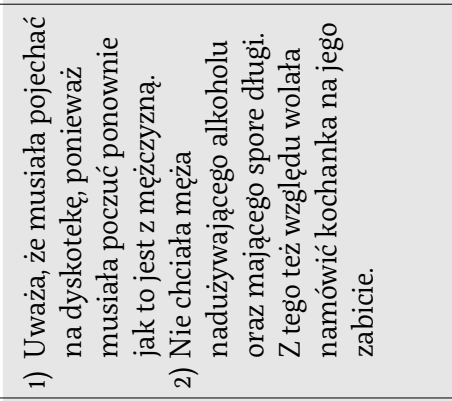 } \\
\hline 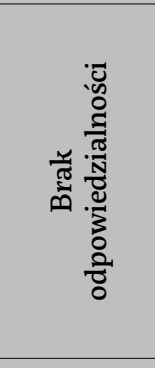 & 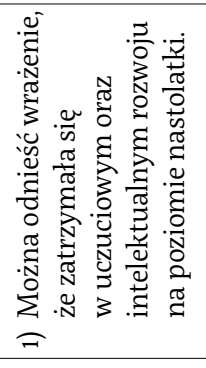 & & \multicolumn{2}{|c|}{ 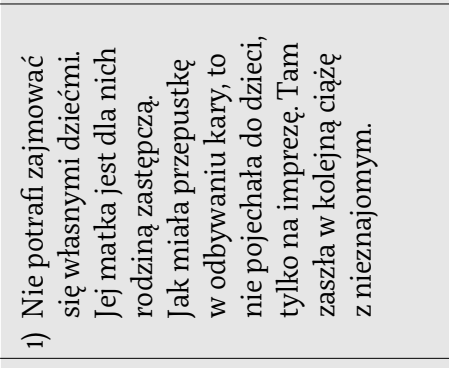 } \\
\hline 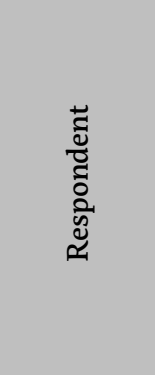 & 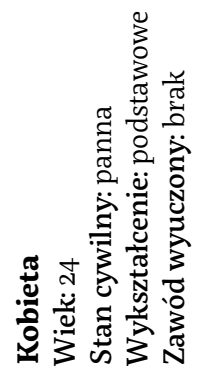 & 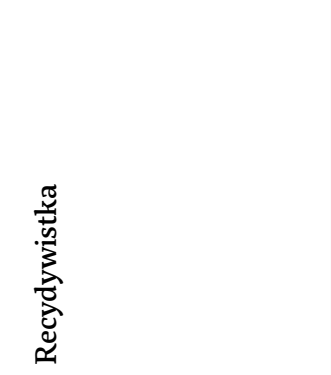 & 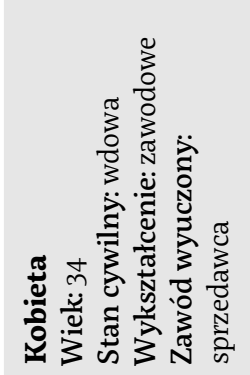 & 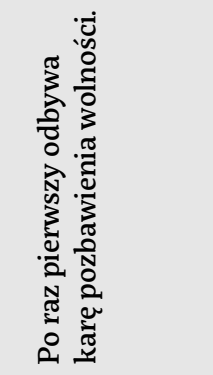 \\
\hline
\end{tabular}




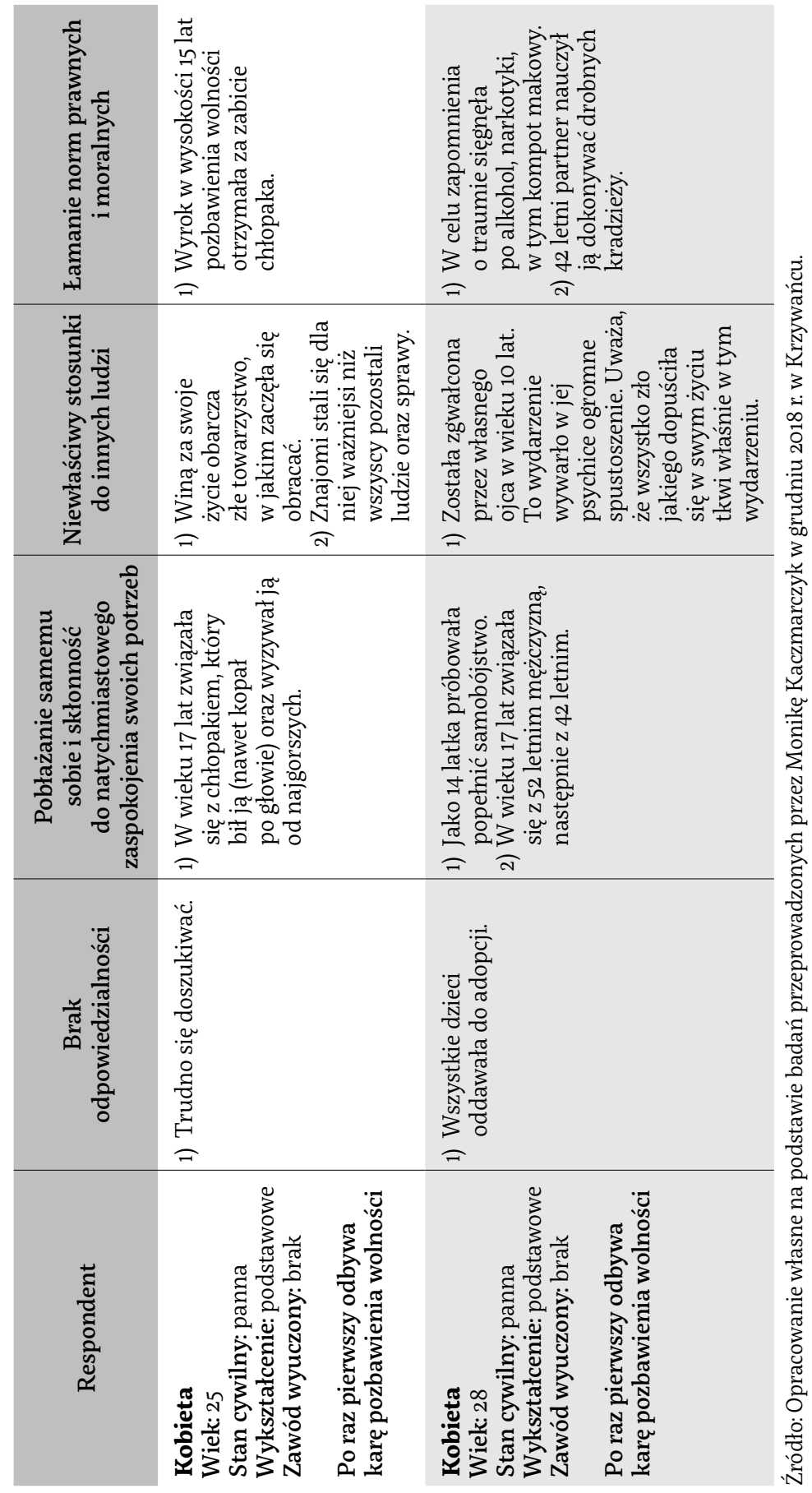


Takie same obserwacje w zakresie biografii uczyniono w stosunku do kobiet, zarówno recydywistek, jak i po raz pierwszy odbywających karę pozbawienia wolności.

W tabelach ukazane zostały informacje pozyskane w trakcie prowadzonych badań nad biografiami kobiet i mężczyzn odbywającymi karę pozbawienia wolności. Wskazują one, jak wyglądały drogi życiowe przedstawicieli obu płci. W większości przypadków kobiety wychowywały się w rodzinach patologicznych, w których rodzice nadużywali alkoholu lub dochodziło do pobić. W jednym przypadku doszło nawet do gwałtu ojca na 10-letniej córce. Natomiast w przypadku mężczyzn należy stwierdzić, że przyczyny popełnionych przestępstw w większości wynikają z chęci szybkiego dorobienia się, zaimponowania rówieśnikom lub rodzinie, zazdrość w związkach oraz alkoholizm. Kobiety niejednokrotnie lubią stawać w pozycji ofiar, panowie zaś w aktywnych i odważnych macho. W wielu życiorysach kobiet nie można twierdzić, że jest to przestępczy styl życia, raczej ma się do czynienia ze stylem ofiar przemocy domowej. Ciekawe jest to, że takie twierdzenie mieści się w drugim założeniu sformułowanym przez Waltersa, które odnosi się do sposobów interakcji jednostki ludzkiej w strefach fizycznej, społecznej oraz psychologicznej. W przedstawionych biografiach mężczyzn i kobiet odbywających karę pozbawienia wolności ujawniają się liczne nieprawidłowości w budowaniu tych relacji. Widzimy, że w większości są to osoby wywodzące się z rodzin patologicznych. Stosunkowo wcześnie zaczynały one spożywać alkohol i/lub narkotyki. W wielu przypadkach aktywność seksualna rozpoczęła się już w szkole podstawowej lub w gimnazjalnej. Zatem ten warunek należy uznać za spełniony.

Warto nieco dłużej zatrzymać się przy trzecim warunku. Wolters twierdzi, że pewne życiowe okoliczności mogą zmuszać jednostki ludzkie do dokonywania wyborów, które powodują, że człowiek wkracza na drogę przestępczości. Zaznacza jednak, że nie determinują one dokonywanego wyboru ${ }^{17}$. Tym samym według teorii przestępczego stylu życia badani mogli wbrew złym warunkom występującym w ich młodości nie rozpocząć życia w znacznej mierze polegającego na łamaniu prawa. Badane wycinki biografii zaprezentowane w powyższych tabelach wskazują, że osoby skazane miały określone momenty przełomowe w swoim życiu. Znajdując się w takich życiowych sytuacjach, podejmowały one decyzje, które doprowadziły do popełniania czynów

17 M. Ciosek, Psychologia sq̨dowa i penitencjarna, s. 69. 
karalnych. W dużej mierze były one podyktowane chęcią obrony przed pijanymi i agresywnymi mężami czy partnerami. Z informacji zawartych w tabelach można się również dowiedzieć, że wstąpienie na drogę przestępczości spowodowane było złą sytuacją rodzinną. Z przeprowadzonych wywiadów wynika, że łamanie prawa mogło być wywołane pośrednio agresją w szkole lub w domu. Przy czym warto pamiętać, że badane kobiety zawsze mogły dokonać wyboru. Fakt, że w domu była agresja, nie oznaczało automatycznie dopuszczenia się jakiś przestępstw. To właśnie kwestia dokonanego wyboru podyktowana wówczas istniejącymi uwarunkowaniami wpłynęła na to, że osoby te stały przestępcami.

Czwartym założeniem jest to, że większość decyzji podejmowanych przez osoby wchodzących na drogę łamania prawa sprowadza ich życie ku katastrofie. Wszystkie przedstawione wycinki biograficzne wskazują, że właśnie tak było. Przykładem potwierdzającym jest życie 53-letniego tokarza-ślusarza, ujętego w powyższym zestawieniu. Warunkiem startowym było to, że posiadał rodziców, którzy tolerowali jego lekkie i przyjemne życie. Po zakończeniu szkoły nie podejmował żadnej pracy, rodzice nadal go utrzymywali. W trakcie jednego z wypadów poznał dziewczynę, z którą chciał rozpocząć wspólne życie. Fakt, że była młodsza od niego, to nadal chciała się bawić, chodzić po dyskotekach. Na jednej z takich zabaw poznała nowego, młodszego chłopaka. Konsekwencją nowej znajomości był rozwód, co wywołało u ślusarza załamanie. Zaczął spożywać alkohol w nadmiernych ilościach. Oprócz tego w celu zarobienia łatwych pieniędzy zaangażował się w kradzieże, trochę później w handel narkotykami. Po jednych ze swoich rozbójniczych akcji poznał w barze dziewczynę, której chciał zaimponować, dlatego pobił jednego z biesiadników. Związek ten nie przetrwał długo, ponieważ nowej partnerce przeszkadzało to, że handlował i zażywał narkotyki. Chcąc zerwać z dotychczasowym procederem, musiał znaleźć nowe źródło utrzymania, którym stały się kradzieże. To spowodowało, że dość szybko został aresztowany i osadzony w więzieniu. Po powrocie dowiedział się, że jego partnerka poznała nowego chłopaka, mężczyzna coraz częściej brał więc udział w kradzieżach, również na terenie Holandii. Po jakimś czasie ponownie trafił do więzienia. W tym przypadku decyzje o angażowaniu się w nieudane związki oraz chęć zarobku dużych i łatwych pieniędzy doprowadziły do katastrofy w jego życiu. Polegała ona na utracie dotychczasowej partnerki oraz kilkakrotnym aresztowaniu. W takim samym stopniu katastrofy życiowe zdarzały się w biografiach innych badanych osób. 
Wyżej opisana biografia oraz wszystkie historie przedstawione w tabeli wskazują na pewien przestępczy system myślenia badanych osób. Ten rodzaj ludzkiej refleksji również został ujęty przez Waltersa w jednym z jego punktów. Co więcej, zdaniem Waltersa wstąpienie na drogę przestępczości należy tłumaczyć właśnie tym, że określona osoba zaczyna myśleć jak przestępca. Co za tym idzie, również postępować $\mathrm{w}$ taki sposób. W przypadku prowadzonych badań wśród osób pozbawionych wolności w Nowej Soli zasadę tą obrazuje przypadek 40-letniego rozwodnika. Wskazuje na to wypowiedź, jakiej udzielił w trakcie prowadzonych badań: „Po kilku latach normalnego życia moja sytuacja znów się pogorszyła, straciłem pracę. Znowu zszedłem na ścieżkę przestępstw: przemycałem papierosy, kradłem w całej Europie. [...] Kradłem wszystko, co mogłem sprzedać. W większości były to radia samochodowe, samochody, elektronika i trwało to około 10 lat". W tym przypadku respondent wskazuje, że to utrata pracy spowodowała, że musiał zająć się pozyskiwaniem pieniędzy z nielegalnych źródeł. Jedna z kobiet zaś wyjaśniała: „W 2005 r. doszło między mężem a mną do tragedii, on podniósł na mnie rękę z nożem, zranił mnie w twarz, a ja w tym momencie złapałam nóż i zadałam mu parę ciosów na oślep, nie panowałam nad sobą, po prostu wybuchłam po tylu latach [...] i dlatego zostałam aresztowana". W tym przypadku chodzi o usprawiedliwienie próby zabicia swojego męża, spowodowana ukrytym wybuchem nienawiści.

Chyba najważniejszym i najbardziej istotnym warunkiem (już siódmym), które wskazał Walters, to wykorzystywanie nadarzających się okazji do popełniania przestępstw. Doskonałym przykładem jest życiorys 23-letniego mężczyzny, który został dealerem, sprzedawał narkotyki, ponieważ potrzebował pieniędzy po tym, jak uciekł z domu, od rodziców, którzy go nie rozumieli. Taki sposób zdobywania pieniędzy podpowiedzieli mu znajomi, których poznał już w gimnazjum. Dzięki temu zajęciu nie tylko mógł się samodzielnie utrzymać, ale również dobrze zarabiać. W tym przypadku to okazja przyszła do niego sama, od kolegów.

Kolejnym założeniem, jakie Walters przedstawił, jest funkcjonowanie mechanizmu motywującego do rozpoczęcia oraz kontynuacji przestępczego stylu życia. Polega ona na następowaniu po sobie takich elementów jak: złość bunt - kontrola (ewentualnie podniecenie) - przyjemność lub chciwość - lenistwo $^{18}$. Warto zaznaczyć, że nie wszystkie te elementy muszą występować,

18 Tamże, s. 69. 
wystarczyło, że istniał jeden z trzech wyżej przedstawionych bloków. W pierwszym przypadku te trzy elementy występowały u większości kobiet. Duża część z badanych biografii wskazuje, że kobiety wychowywane w patologicznych rodzinach przeżywały okres buntu. Charakteryzuje się on tym, że uciekały z domów lub ze szkoły, wagarowały. Szybko też poznawały mężczyzn i wchodziły z nimi w związki, które okazywały się podobne do tych, od jakich uciekły. Próbą odzyskania kontroli nad własnym życiem było popełnienie przestępstw wobec partnerów. W drugim przypadku był to mechanizm, który dotyczy zarówno mężczyzn, jak i kobiet. Dokonywane kradzieże lub handel narkotykami spowodowany był chęcią szybkiego zdobycia pieniędzy. Wszystkie elementy przedstawionych biografii wskazują, że istniały ścisłe związki pomiędzy sposobem myślenia badanych, a tym, jak wyglądało ich życie. Stanowi to następny wniosek, jaki został sformułowany przez Waltersa.

We wszystkich wypowiedziach osób pozbawionych wolności, jakie brały udział w prowadzonych badaniach z łatwością można odnaleźć warunki określone przez Waltersa. Właśnie one wskazują, że życie osób badanych przybiera przestępczy tryb życia. Trzeba dodać, że termin „przestępczy styl życia” oznacza, że w jakieś części wstąpienie na ścieżkę przestępczości było dobrowolne, nie wynikało to z przymusu. Oczywiście należy brać pod uwagę, że na to, iż badane osoby wybrały przestępczy styl życia, miały m.in.: otoczenie, wzorce osobowe. Jednak ostateczna decyzja wynikała z dobrowolnie podjętej decyzji. Analiza poszczególnych biografii pozwala na stwierdzenie, że popełnienie przestępstwa nie jest spowodowane jednym czynem, ale istnieje ciąg wydarzeń zmierzających ku temu aktowi. Jest to skomplikowany proces, który niejednokrotnie zaczyna się od wczesnych lat dzieciństwa. Zastosowanie metody biograficznej jednoznacznie pozwala odkryć istnienie całych łańcuchów przyczynowo-skutkowych prowadzących do przyjęcia przestępczego stylu życia. W wielu przypadkach mogą występować różnorodne uwarunkowania, jednak mechanizmy są do siebie bardzo zbliżone. Zastrzeżenie różnic pomiędzy stylem życia ogólnie rozumianym na gruncie socjologii i ekonomii a tym, jaki zaproponował Walters, pozwala na zrozumienie, na czym właściwie polega „przestępczy styl życia. Dodatkowo stosowana w praktyce teoria pozwala na zaprojektowanie właściwego indywidualnego procesu resocjalizacji. W tym przypadku poznanie biografii skazanych osób jest bardzo przydatne. Poznanie współzależności prowadzących do popełnienia przestępstwa lub przestępstw powoduje, że resocjalizacja 
może przynieść pozytywne skutki. Oznacza to, że metoda biograficzna powinna jak najszerzej być propagowana zarówno na studiach, jak i wśród pracowników odpowiedzialnych za przebieg procesu resocjalizacji. Poznanie biografii każdej osoby odbywającej karę pozbawienia wolności (jak i innych osób wymagających resocjalizacji lub innych form pomocy), jej problemów, sytuacji emocjonalnej i materialnej pozwoli na lepsze, indywidualne udzielenie pomocy. Warto jednak zaznaczyć, że nie ma większego sensu organizowanie wykładów czy też form nauczania o charakterze teoretycznym. Taka wiedza zazwyczaj jest nieprzyswajalna i szybko zapominana. Powinno się jednak organizować cykliczne szkolenia o charakterze praktycznym, które zmierzałyby do prowadzenia resocjalizacji wykorzystującej doświadczenia życiowe osób skazanych lub też znajdujących się w innych ośrodkach. Nauka oraz szkolenia utrzymałyby wśród osób pomagającym innym otwartość na indywidualne problemy innych. Stworzyłyby umiejętności praktyczne w zakresie niesienia pomocy w oparciu o indywidualne biografie tych osób. Warto również zastanowić się nad tym, czy nie warto zatroszczyć się o opracowanie zbioru procedur, które poprawiałyby pracę nad resocjalizacją w oparciu o metodę biograficzną przy wykorzystaniu teorii przestępczego stylu życia. Postulat ten bierze się z tego, że istnienie odpowiednich procedur pozwoliłoby maksymalnie wykorzystywać metodę biograficzną wśród różnego rodzaju wychowawców. Takie działania stanowią również odpowiedź na dosyć powszechne w społeczeństwie przekonanie o nieskuteczności działań resocjalizacyjnych. Dotykanie ludzkich problemów i niesienie pomocy osadzonym może okazać się skuteczną metodą pozwalającą na powrót osób odbywających karę pozbawienia wolności na wolność. Spersonalizowany i zindywidualizowany proces resocjalizacji zbudowany na metodach jakościowych może okazać się rozwiązaniem, jakiego dotąd poszukiwano, a który przynosiłby lepsze efekty.

Streszczenie: „Styl życia” jest pojęciem, które uległo dużej popularyzacji w ostatnich latach. Wykorzystywane jest ono w języku marketingu, reklam czy też w kolorowych pismach oraz serwisach społecznościowych. Teorie dotyczące stylu życia powstały na gruncie nauk społecznych na przełomie XIX i XX stulecia. Wśród wielu teoretyków znalazł się nawet Max Weber. Pojęcie „przestępczy styl życia” w jakimś ograniczonym stopniu nawiązuje do tych wcześniejszych koncepcji. Odróżnienie tego zjawiska od ogólnego pojęcia "stylu życia" pozwala na lepsze zrozumienie przyczyn, jakie motywują ludzi do popełnienia przestępstw. Wykorzystanie metod ilościowych w przypadku rozpatrywania teorii przestępczego stylu życia nie doprowadziło do dokładanego poznania 
genezy tych zjawisk i zachowań oraz praktycznego ich wykorzystania. Spowodowane to było tym, że wyniki w dużej mierze nie odzwierciedlały społeczno-psychologicznych uwarunkowań przestępczego stylu życia. Z tej racji za najlepsze należy uznać wykorzystanie metod jakościowych, wśród nich zaś metodę biograficzną. Polega ona na poznaniu całej biografii osób skazanych - od najwcześniejszych lat dzieciństwa do chwili obecnej. Narzędzia i techniki, jakie są wykorzystywane, to nie tylko wywiad prowadzony z osobami skazanymi, ale analiza różnorakich źródeł pisanych, w tym dokumentacji tworzonej przez samych badanych oraz dokumentów z zakładów karnych. Poznanie życiorysów mężczyzn i kobiet odbywających karę pozbawienia wolności jako metoda badawcza pokazuje, że teoria przestępczego stylu życia ma praktyczne zastosowanie w klasyfikacji zachowań przestępczych. Proces resocjalizacji wykorzystujący metodę biograficzną oraz analizę zdobytego materiału badawczego w oparciu teorią o przestępczym stylu życia wydaje się na tyle skuteczny, że może być wykorzystywany w praktyce z dużymi sukcesami. Jest tylko jeden warunek, osoby ją wykorzystujące muszą posiadać odpowiednie umiejętności praktyczne.

Słowa kluczowe: styl życia, przestępczy styl życia, biografia, życiorys, zakład penitencjarny, resocjalizacja, kara pozbawienia wolności, mężczyźni, kobiety, recydywiści, zakład karny, więzienie, przestępstwo.

\section{Bibliografia}

Bron A., O badaniach biograficznych krytycznie, „Nauki o Wychowaniu. Studia Interdyscyplinarne", 4 (2017) nr 1, s. 16-34, DOI:10.18778/2450-4491.04.02.

Ciosek M., Psychologia sądowa i penitencjarna, Warszawa 2003.

Cisek S., Metodologia jakościowa we współczesnej informatologii. Wybrane aspekty, "Przegląd Biblioteczny", 3 (2013) s. 299-310.

Czyżewski M., Socjologia interpretatywna i metoda biograficzna. Przemiana funkcji, antyesencjalistyczne wątpliwości oraz sprawa krytyki, „Przegląd Socjologii Jakościowej", 9 (2013) nr 4, s. 14-27.

Denzin N. K., Reinterpretacja metody biograficznej $w$ socjologii. Znaczenie a metoda $w$ analizie biograficznej, w: Metoda biograficzna $w$ socjologii, red. J. Włodarek, M. Ziółkowski, Warszawa-Poznań 1990, s. 55-69.

Gruszczyński W., Jeszcze raz o systemie, normie i uzusie, w: Polszczyzna moja.... Księga jubileuszowa z okazji 40-lecia pracy naukowej i dydaktycznej profesora Jerzego Bralczyka, red. G. Dąbkowski, D. Lewandowska-Jaros, Warszawa 2009, s. 109-119.

Halamska M., Żyć na wsi. Elementy stylu życia, „Wieś i Rolnictwo”, 1 (2021) s. 25-43.

Kłos J., Zjawisko zdrowego stylu życia we współczesnym społeczeństwie polskim, Poznań 2014. 
Malewski M., Badania jakościowe wobec postulatu teoretyczności wiedzy, w: Krytyka metodologiczna $w$ praktyce tworzenia wiedzy, red. J. Piekarski, D. Urbaniak-Zając, S. Pasikowski, Łódź 2020, s. 91-98.

Metody badań jakościowych. red. N. K. Denzin, Y. S. Lincoln, t. 1-2, Warszawa 2011.

Pękala J., Życie jako biografia. Podejście biograficzne w perspektywie pedagogicznej, Danuta Lalak [recenzja], „Forum Pedagogiczne”, 1 (2014) s. 275-278.

Pieciuch T., Molter A., Metody jakościowe w badaniach przedsiębiorczości, „Problemy Zarządzania", 12 (2014) nr 3, s. 248-268.

Pietkiewicz I., Smith J. A., Praktyczny przewodnik interpretacyjnej analizy fenomenologicznej w badaniach jakościowych w psychologii, „Czasopismo Psychologiczne”, 18 (2012) nr 2, s. 361-368.

Piotrowska D., Styl życia. Uwagi ogólne, „Zeszyty Naukowe Wyższej Szkoły Pedagogicznej w Bydgoszczy. Studia z nauk społecznych", 2 (1998) s. 61-77.

Sciński A., Styl życia - problemy pojęciowe i teoretyczne, w: Styl życia. Koncepcje i propozycje, red. tegoż, Warszawa 1976, s. 15-32.

Sowa I., Wykorzystanie koncepcji stylu życia $w$ typologii młodych konsumentów, „Studia Ekonomiczne. Zeszyty Naukowe Uniwersytetu Ekonomicznego w Katowicach", 303 (2016) nr 7, s. 135-149.

Stanik J. M., Psychologia sądowa: podstawy, badania, aplikacje, Warszawa 2013.

Szymański A., Przestępcze style myślenia osadzonych $w$ zakładzie karnym a działania penitencjarne, w: Praworządność $w$ dobie XXI wieku, red. J. Zimny, Stalowa Wola 2016, s. 423-425.

Toroń B., Przestępczość skazanych kobiet i mężczyzn w perspektywie biograficznej, Kraków 2013.

Toroń-Fórmanek B., Proces resocjalizacji osób pozbawionych wolności $w$ aspekcie nieharmonijnego rozwoju tożsamości, „Lubelski Rocznik Pedagogiczny”, 35 (2016) nr 2, s. 85-101, DOI: 10 17951/lrp 201635285. .

Walters G. D., Modeling the Criminal Lifestyle. Theorizing at the Edge of Chaos, Kutztown 2017.

Wszołek M., Styl życia w komunikacji społeczeństwa, „Studia Ekonomiczne. Zeszyty Naukowe Uniwersytetu Ekonomicznego w Katowicach", 313 (2017) s. 187-197.

Zalewska J., Kategorie stylów życia w twórczości naukowej Elżbiety Tarkowskiej, w: Socjologia czasu, kultury i ubóstwa. Księga jubileuszowa dla profesor Elżbiety Tarkowskiej, red. K. Górniak, T. Kanasz, B. Pasarnonik, J. Zalewska, Warszawa 2015, s. 157-166. 